\title{
Continuing attachments in academic work in neoliberal times: On the academic mode of existence
}

\author{
Mathias Decuypere and Maarten Simons \\ Laboratory for Education and Society, University of Leuven, Leuven, Belgium \\ mathias.decuypere@,kuleuven.be
}

\begin{abstract}
Is there (still) something specific about academic practice in contemporary neoliberal times? This article reports on a sociomaterial, ethnographic study informed by Deleuze's untimely empiricism conducted at two research centres of a research university. We unfold the specificity of 'the academic' by elaborating upon two central notions: relational aspirations (the attachments of these academics, and the operations that such attachments generate) and mode of existence (the way academic practice comes into being by and through these attachments). The article discerns four types of relations that are typical for academic practice and argues that the way in which academic practice exists nowadays is characterized by a continuous distancing in action, that is, by drawing things together and by slowing things down.
\end{abstract}

\section{To cite this article:}

Mathias Decuypere and Maarten Simons (2017). Continuing attachments in academic work in neoliberal times: On the academic mode of existence. Critical Studies in Education. (In Press.)

DOI:10.1080/17508487.2016.1240095

\section{Available at:}

http:/ / dx.doi.org/10.1080/17508487.2016.1240095 


\section{Introduction}

The current condition of the university has been scrutinized intensively over the last years, and in many respects, the documented results of these investigations are - to put it mildly - not particularly encouraging. Increased administration, growing marketization, budget cuts, reduction of personnel, the diminishing of fundamental research, publication pressure, ...: the list is long and continues to expand (e.g. Barnett, 2011; Lynch, 2015; Petersen, 2009; Torres, 2011). By and large, the current condition of the university is framed in terms of neoliberalism as the concrete type of governing that is being imposed on academic institutions (Harvey, 2005). Taking stock of the critical literature on the current condition of the university, most studies can largely be situated either in a critical-institutional or in a critical-personal approach. Even though both approaches share the tendency to be critical of neoliberal evolutions in, and measures imposed on, the university, they do tend to stress different things.

First, it has been argued that neoliberal logics have deeply penetrated into university policies all over the globe and have become the primordial paradigm in contemporary university governance (Marginson \& Considine, 2000; Slaughter \& Rhoades, 2004). There is a growing consensus that the neoliberal ideology has dramatically impacted on and reshaped more traditional ways of university management and policy, and this in the direction of more (and accelerating) commercialization, privatization, deregulation, etc. (e.g. Giroux, 2002; Olssen \& Peters, 2005; Shore, 2010). Critical studies in this vein largely adopt an organizational approach, which aims to come to an understanding of (the impact of) these evolutions on the university as a whole. The university is then often theorized in terms of its specificity and unicity, for instance by stating that it is not a corporation (Nussbaum, 2010). The organizational approach contributes to our understanding of the university as an institution, that is, as an organization adhering to a particular idea and with delineated social functions (such as research, teaching and service provision), which are all under increased pressure given the dominance of neoliberal doctrines (Guzmán-Valenzuela, 2015; Lenartowicz, 2015; Macfarlane, 2011; Simons \& Masschelein, 2009).

A second strand of critical studies focuses on how concrete dimensions of the personal lives of individual academics are equally heavily impacted by neoliberal doctrines and regimes, how specific academic activities are consequently being reshaped and reconfigured under the auspices of these neoliberal ways of thinking and conduct, and so on (Vander Kloet \& Aspenlieder, 2013). This second strand approaches the university not through an institutionary lens, but rather through a detailed inspection of the personal lives of the academics present in this institution. In this approach, the experiences, opinions, and sense-making of academics are focal points of analysis (typically through interviews or surveys). This more personal approach enables to understand how academics experience this current condition on a daily basis, for instance, how processes of marketization have a concrete influence on the daily functioning of academics; how one's workload is being perceived precisely; etc. (e.g. Collyer, 2015; Hakala, 2009; Ylijoki, 2014).

Even though different in focus, both approaches furthermore argue that the con- sequences of these processes are especially detrimental for the humanities and for research of more fundamental nature (although it is often added that all scientific disciplines are to a more or lesser extent susceptible to such evolutions). The 'crisis in the humanities and fundamental research' is then often situated in their difficulties with adapting to neoliberal expectations such as the production of economically valuable results (Harpham, 2005; Nussbaum, 2010). The reason for these difficulties is related to a different kind of logic on which these research strands are based, that is, on a logic which operates under the premise that the university has an inherent public character (East, Stokes \& Walker, 2014; Giroux, 2002; Marginson, 2011). With the gradual erosion of the public character of higher education in favor of increasing privatization, it has equally been presaged that the university - as the institution that we have come to 
know over the last centuries - is bound to disappear itself (Readings, 1996). Related to the erosion of the public character of the university, both approaches have equally argued that the introduction of neoliberal thinking and governance has not only led to assumptions that knowledge should be made more profitable, output oriented, etc. but also led equally to a devaluation of what we commonly hold as 'academic' (e.g. academic freedom, thought, scientific integrity, etc. - Bok, 2003; Donoghue, 2008).

In view of these general developments, it is tempting to surmise that neoliberalism - both as a conceptual means to probe the general condition of the university and as an investigatory tool allowing to circumscribe specific neoliberal manifestations in concrete academic practices - has penetrated into each and every aspect of the university (Nóvoa, 2015). That is to say, the growing emphasis on neoliberal influences and attention for its detrimental effects tends to convey the impression that neoliberalism, as a dominant way of thought and mode of existing, has diffused through the majority of the university's inhabitants: that all academics have become entrepreneurs and competitors, that all students now behave according to a market logic, etc. However, despite being a global trend, neoliberalism manifests in a variety of ways and does not constitute a (completed) reality in all universities or for all academics (Barnett, 2011; Ong, 2007).

The aim of this article is not so much to question these evolutions and/or their documented manifestations, but rather to question whether that is all there is (that needs to be said). More precisely, this article starts from the assumption that academic practices (still) possess certain typical features and characteristics which distinguish them from other sorts (e.g. governmental, corporate, neoliberal, ...) of practices. Adopting an approach outlined by Deleuze (1994), we aim to undertake an exercise in untimely empiricism, that is, an empiricism that does not seek to react against neoliberal concepts and/or established research approaches of the university, but rather one that tries to probe the current condition of the university by searching for ways and concepts that allow different, other, accounts of the university to appear. Deleuze (1994, xxi), after Nietzsche, conceives of such an untimely attitude to our present as one that is 'acting counter to our time and thereby acting on our time and, let us hope, for the benefit of a time to come'. Such empiricism seeks to conceptualize different ways of thinking about the university, both by conceiving its condition through the lens of what happens today, and by acting on - and giving alternatives to - what happens today (Rose, 1999; Simons \& Masschelein, 2009).

Adopting an untimely empiricism, the critical approach that will be adopted in this article is neither directed at the level of the individual nor at the level of the university's structure or idea. Instead, we approach the university as being 'in the making', rather than being made (by marketization or commercialization, for instance). This is not to say that we deny such influences and their consequences, but rather that the current condition of the university can equally be scrutinized 'from within', that is, by focusing on what happens in concrete academic practices (Alvesson, 2003; Bourdieu, 1988; Hamon \& Rotman, 1981). How are such practices composed precisely on a day-to-day basis? How do academics (as the persons who 'work' in the university, that is, persons who effectuate research, teach, have various meetings with other faculty and broader society, etc.) act in these practices? Such issues are not primarily pertaining to the role, meaning or intrinsic value of the university, but rather to how the university is concretely enacted through academic practice. Surprisingly few studies have been conducted that seek to come to grips with what it is that professors and other faculty do concretely, based on descriptions of what happens precisely in daily practices - and this without invoking general overlying contexts or structures (e.g. neoliberalism and marketization), personal qualification and meaning-giving (e.g. perceived workload, recognition), or critical-normative views that prescribe what the university should be for (e.g. fostering citizenship and democracy; advancing knowledge; educating students as critical persons). Put otherwise, what has received little consideration is how precisely the university is given shape by concrete 
academic practices conducted on a day- to-day basis. Such analyses do exist, but are most of the time to be found in ethnographic accounts of the positive sciences (for instance, Callon, 1986; Latour, 1987; Mol 2002). These studies are all directed at the question of how 'science' is enacted through research, however, and not as much at how 'the university' is enacted through academic practices.(1) In the vocabulary of these science and technology studies, one could state that 'academic practice' - the complex interplay between various actors that results in specific doings, sayings, activities, understandings and routines - at present largely constitutes an underinvestigated 'black box' (Decuypere \& Simons, 2014; Landri, 2012).

\section{Opening the black box}

The intention of the present article is to open up this black box by means of a case study. In order to do so, we visited two research centers, broadly situated somewhere in the humanities. The research centers are located in the social sciences faculty of a (European) research university. Even though they function independently of each other, they operate in the same discipline and physically share the same corridor in the faculty building. As a general impression, these two centers house about 10 professors and about 40 other members of academic staff (Ph.D. students, postdoctoral researchers and teaching assistants). By means of intensive fieldwork, we followed these academics during the conduct of their daily work for a period of 3 weeks (full time). Our fieldwork, hence, is to be conceived as focused or short-term ethnographic inquiry (Knoblauch, 2005; Pink \& Morgan, 2013). During this period, the corridor constituted the nexus of our investigations: this was the point where we started each day and to which we returned after some activity ended (see also Decuypere \& Simons, 2016a). Furthermore, as agreed with the heads of the two research centers, except for individual activities (e.g. writing an article, reading a book, answering e-mails), we were granted formal permission to observe all activities taking place either at the corridor or some- where else. Consent of individual participants was always informally obtained before starting an observation (cf. Murphy \& Dingwall, 2007). A broad variety of activities was observed, such as supervisory meetings between professors and M.Sc. students; strategic meetings between the heads of the research centers; lectures; conferences and study days some academics were attending outside of the research centers; etc.

By means of this ethnographic study, the aim of this article is to come to an understanding of what is being implied precisely when we - often unreflexively - designate the things happening at a university as being 'academic'. In other words, the aim of this article is to unfold what is precisely associated with the term 'academic', by analyzing concrete daily activities at two research centers. This is closely related to Latour's (2013) inquiry into contemporary modes of existence, which aims to disentangle the typical ways of being that characterize various forms of collective life (AIME, 2013). To be clear, the concept 'mode of existence' is not deployed in order to invoke some sort of essence or a generalizing amalgamation of unitary principles (as if there would be one singular manner of existing as an academic today). Rather than determining where (and when) academic practice is to be universally situated, the interest of this paper is more modest and directed at particular moments on which something emerges that can be qualified as an 'academic' way of relating - and not, for instance, a neoliberal or managerial manner. Guiding questions in this respect were: What are typical aspirations of academics in contemporary universities? Which sorts of relations are typical for academic practices? What are academics typically attached to and interested in (this might be people, but equally objects, concepts, different sorts of space and time, etc.)? (Latour, 1999). 
In order to address these questions, and in line with the previous, we adopt a sociomaterial methodological approach which is focally directed at the relations that are established between actors in different activities (Decuypere \& Simons, 2016b; Feldman \& Orlikowski, 2011; Law, 2009). Conform to sociomaterial ethnographic guidelines (Latour, 1999, 2005; Fenwick \& Edwards, 2010), three different notebooks were used: one that functioned as the logbook of the observed events; one consisting of field notes, excerpts of informal conversations and pictures and one consisting of trials that sought to give preliminary accounts of the observations (focusing on these relations, attachments and emerging typicalities). Throughout the process of data collection and analysis, both social and material actors were taken into consideration, and this without analytically privileging one above the other (Hodgson, 2014; Kittler, 2004).

In what follows, we identify four types of relations that were generally characterizable as being 'typical' for the way activities are effectuated in these research centers and that showcase resilience of the academics working in these research centers against neoliberal doctrines and ways of being - and this is not to be understood as in 'acting against neoliberal rationales and dogmas', but rather as in 'showing another way of relating and being'. These types emerged through the continuing working on (and reworking of) the research material (Hillyard, 2010; Latour, 1999). Slightly reminiscent of a grounded theory approach, the field notes (in what follows fragmentarily depicted as 'scenes') that were generated during the ethnographic field work were continuously analyzed and elaborated upon, both during as well as after the field work was conducted. In and through our working on these field notes, we gradually came to discern four groups of (types of) relations that recurred on a regular basis, and that seemed to account for a typical way of relating as an academic. Hence, rather than prototypical instances of a general phenomenon, the field notes presented in what follows are to be conceived as generative fragments that show aspects of a way of relating that could be qualified as being 'academic'. In that sense, singularly conceived, each group of attachments is not uniquely tied to, or reserved for, an academic way of being. Rather than that, it is only when conceived as a totality that something qualifiable as 'academic' might start to emerge. Hence, the purpose of the scenes introduced below is to gradually showcase an emerging way of relating which cannot be subsumed under the auspices of neoliberal doctrines and manners of conduct, but which rather points to specific types of relating that academics aspire to. Together, all this will allow to say something about the features of an academic way of existing itself.

\section{Purifying}

Scene 1. On a two-day conference on which a professor and two Ph.D. students of one of the research centers are present, two foreign researchers are presenting their work. The first day of the conference is drawing to a close, and the participants are increasingly looking exhausted. The presentation given by these two researchers is the last one in a slot of three; the slot being moderated by the professor we followed here. The two researchers have prepared a paper which they read out alternatingly. The paper presents a concrete case that was investigated and analyzed by means of online data. In addition to this paper, the presenters have equally prepared a slide show, which is projected on the front wall of the room. The slides present a variety of visual elements such as pictures of flyers and brochures, YouTube films and print screens of these YouTube films. All visual elements are directly related to the case at hand. Sometimes, however, the slides are primordially textually oriented, displaying bulleted lists of focal elements of their paper. The larger part of the paper is centered around this particular case, about which some more general arguments are derived. At the end of the session, a concluding discussion with the entire panel is taking the start. Some general points are being raised, but most prevalent are questions about concepts deployed by the presenters, the particular cases that have been presented, and eventually about their relation with the research discipline itself. 
Scene 2. In view of a master's course directed at getting acquainted with some main topics and concepts of the discipline by means of group work, one group of students is having a preparatory meeting with the course's lecturer. The assignment of these students is to chair a session about the participatory method, a method often deployed by professionals in the field. At the beginning of this meeting, however, the students are raising some issues regarding an assignment that should be fulfilled for another course, given by the same lecturer. For that course, the students have to write a paper about a book they (all) have to read. The students mention that the book is quite inaccessible and difficult to understand. The lecturer takes note of these concerns, but reminds the students that this book is of tremendous importance: 'It is a classic', she emphasizes sharply. A week later, at the end of the actual session chaired by the students, she takes the word again in order to point to a seminar that will take place in the context of another course, where a guest professor will listen to a short presentation each student is expected to give. 'I just want her to know you and vice versa', she says, 'It's an honor to have this professor here. It's a big name'.

Even though these two scenes are very particular renderings of activities taking place in one particular university, they are undoubtedly not unfamiliar to the reader. Conferences and academic education are common activities for most academics, which make them a familiar and fruitful point of departure for the purposes of this analysis. What is 'typical' in these scenes? What do the academics in these scenes aspire to? If the two presenters at the conference - and they are not alone: deploying visual elements happens nearly everywhere and every time - mobilize many visual elements, for instance, what does this point at? Basically, this demonstrates the importance of showing - indeed it is a slide show - particular aspects of a setting (a case) one has investigated, and of which one is presenting several aspects at that moment. This showing is not a trivial action - as if one would merely demonstrate what one has seen. Rather, the process that is specifically in play here is the deployment of particular exemplifications of what was witnessed during one's research activities, not only in order to convince the attending participants but also equally in order to make sense of what one is talking about at that moment. A series of pictures, for instance, does not only operate as a showing device but also equally functions as a particularizing device. By particularizing - that is, by showing highly specific aspects of that what one is talking about an argument that is by itself already centered around particularities (i.e. a case) is gaining in authority: the particularization of the particular makes it possible that some general arguments about this specific case can be made and that it can be embedded in and related to conclusions and findings of other studies. In doing so, a twofold operation is at work. On the one hand, something particular is further particularized in order to make a general statement. On the other hand, this general statement makes that the particular (e.g. a case) is departicularized: it is made into an instance of something other (a broader phenomenon; a widely recognized evolution; ...). Computers, and more especially screens, play a decisive role herein: by means of their capacity to project these particularities into series, or more appropriately, into carousels of visualizations, they enable to project a profusion of particularities, in such a way that the legitimacy and the objectivity of the presenter's argument is rising. All this could be conceived as an activity of purifying particularities, and this not in the sense of stripping something to its essence, but rather in the sense of increasing the concentration of the argument one makes. By particularizing the particular (in order to make a general statement) and departicularizing it thereby in one and the same process (making it an instance of something other), a central concern here is that what one generally states as an academic is 'right', that is, in accordance with what one saw (in the field), but equally that what one states is not particular as such: it is an instance of something other. Consequently, one's statements are increasingly concentrated: they gain more value and meaning in so far as one succeeds in deploying the particular (carousels of specific pictures) in order to make a general argument (an instance of larger processes at work, for instance). 
This interest in generality by purifying particularities is additionally exemplified by the central importance of fieldwork anecdotes and stories, which are omnipresent throughout all activities in the corridor (in conference presentations and lectures, during coffee breaks, in research seminars, etc.). 2 Again, these anecdotes and stories are way more than mere illustrations tied to a general point one wants to make. Rather than that, it is the other way around: without these anecdotes and stories, there would not be any scholarly point to make. By narrating about one's experiences in the research field - this again constitutes a particularization of the particular: the particular case is further particularized by relating one's own experiences to it - the same twofold operation is inaugurated. First, the instauration of tangibility about what one is talking about (and therefore nearly always uttered at the beginning of a lecture, conference or seminar and often elaborated throughout the course of the activity) so as to ascertain that one makes sound claims and arguments. Therefore, these stories are not randomly chosen: they need to be the story or anecdote that corresponds best with the general point one intends to make. Second, the generation of a specific kind of objectivity: by means of reporting about detailed particularities one has been confronted with, the kind of objectivity that is generated in these academic practices is about the level of detail one is able to generate, the number of different viewpoints one is able to incorporate and the way one is able to transform both of these into general, concentrated and pure(r) claims about the particular, and hence not/less about the establishment of neutral, solid and universal scientific facts (Venturini, 2010).

Finally, making use of specific elements is not confined to the purification of the particular and a concomitant aspiring to generality, however. As the second scene illustrates, academics in this corridor are often equally passionately interested in, and relating toward universalities. Just like generalities, universalities are never a priori established. Rather, they need to be enacted as something universal, and this happens through revering singular actors: this person (and not another); this classic (and not another). At the same time, however, this implies purifying these singular actors (a colleague, a book) - this time not into a generality but rather into a universality: something, or someone, singular that other actors are expected to be equally and universally in reverence about. Again, this is not a question of essentializing a human into a name or a book into a title, but rather a matter of concentration: names and titles are a concentration (of a singular academic into a name, of a singular book into a title) that enables to revere singular actors as universal eminences. By this act of purifying, these eminences are thereby endowed with a substantial amount of authority (rather than objectivity), which one expects to treat with awe and respect.

\section{Authorizing}

Scene 3. In a well-attended session, a Ph.D. student is about to present some of his preliminary research results. As a guest speaker, he first introduces himself by stating that he 'effectuates the research of professor X'.

Scene 4. An academic has just returned from a conference. He meets a colleague in the corridor, who asks him how his paper presentation went. 'Very good', he says to her, 'I have received very good comments, especially from $Y$ '. His colleague affirms that it is tremendous news that $Y$ (an academic from abroad) was positive about the project the paper reported of. Y has good relations with both research centers, and the colleague additionally advances the possibility that $\mathrm{Y}$ could be invited to pay a visit at the corridor.

Both scenes exemplify concrete ways in which the academics in these research centers often understand themselves in terms of, and relate toward, the concrete research activities they undertake (such as presenting a paper, writing articles, etc.). The third scene, for instance, showcases a Ph.D. student who 
conceives of his research activities as not only (and not even chiefly) ascribable to himself but also equally to a coordinator of the overarching research project he is involved in. In doing so, one authorizes the work one conducts (i.e. as a Ph.D. researcher) through the name of somebody other (X). The same applies for the fourth scene, in which personal research activities are equally authorized, but this time by relating them to the opinions of somebody other $(\mathrm{Y})$. What is established in these scenes is thus a very specific sort of relation that authorizes through (de)personalization. First, by relating one's research to other persons, this research is being depersonalized in order to authorize what one is doing: it is made less of oneself, and more (or equally) of somebody other. Hence, this depersonalization is, second, at once a repersonalization: by authorizing one's research through somebody other, not only is one's own research gaining in authority, also these other persons are being rendered important likewise.

Scene 5. We are strolling through the faculty building to the coffee room, which is shared with other centers of the faculty. We are passing a wall containing a collection of articles, published both in scientific journals and in popular newspapers. Our attention goes to this wall, but we are quickly interrupted by one of the academics we are accompanying. 'These are from the other centers', he says. 'Look at that. Articles. At least we have a fully-stuffed bookcase', he jokes, referring to the collection of disciplinary books displayed in the reception area of his own center.

Scene 6. A professor and a student who makes his master's thesis under his supervision are having a meeting. By reading through the notes he brought along, the student elucidates his research proposal and proposes his methodological framework. The professor listens carefully to the student, and after the student is finished, he judges at once: 'The size and scope are not big enough for a study in our discipline', he says. He proposes to broaden up the scope and mentions a few concrete possible directions. 'This way', he states, 'you will be able to conduct a study true to the discipline. There's much literature about this matter in our own discipline as well'.

These scenes again display acts of authorization - this time by relating to the larger discipline one is embedded in. The general discipline one situates oneself in, is of central importance in the corridor and manifests itself both in the activities conducted and in how one presents oneself to its visitors: not only does it create a collective (our discipline), this collectivizing at once constitutes an inscribing of what can and cannot be done, and hence, authorizes oneself as somebody within that discipline. In other words, relating toward and creating collectives likewise implies something that needs to be nourished and protected and that one deeply cares about, but equally and at the same time implies an authorization of oneself and of what one can and is allowed (or deemed valuable) to do (cf. Dall'Alba, 2012).

In sum, no matter when academics talked about their own research, the center one belongs to or the discipline one is situated in, relations that authorize what one does and cares for are constantly established. Even though such relations are most of the time minor comments or moments in a conversation (often mentioned in passing), they point to significant moments of academic personalization. Authorizing one's own individual research through a particular professor, for instance, is not something one does in order to reduce one's own agency as a researcher. Rather, it constitutes an act of inscribing it in a larger whole, under the name of the (authority of this) professor, and thereby at once an act of personalization which enables to become someone oneself. The same applies to disciplinary interest: being passionately interested in one's discipline is not so much a matter of not wanting to engage in interdisciplinarity as it is a means for ascertaining that the discipline in which one is acting, is at once sustained and reinforced, and for oneself, in order to be somebody within that discipline. 


\section{Commoning}

Where, and when, are the academics from this corridor to be found? All academics here have a large concern - a profound attachment - with the proper organization of their activities, and hence with specific sorts of space and time they deliberately seek to create: daily routine activities are so dispersed and largely require individual efforts (e.g. giving a lecture, supervising students) that the creation of shared space and time is something that needs to be watched over constantly. An illustration of this are the weekly 'savage slots' that these two centers share: in operation only recently and proposed by the head of one center, each academic in the corridor is expected to schedule these slots in her calendar. The finality of these slots differs: there might be a staff meeting, a seminar or some other activity. Yet, what all have in common is precisely that these activities are designed and shaped in order to establish a space and time that is common. A similar initiative that seeks to create common space and time are reading sessions, largely at the initiative of Ph.D. students and with the intention of reading a seminal book together. Overall, being physically present together is not only considered of importance but also equally does not come about naturally and needs to be organized and actively shaped. However, despite the importance attributed to such common spaces and times, most professors mention that such commonness is, in fact, a constraining factor when it comes to conducting activities that they themselves very often call 'work' (cf. Decuypere \& Simons, 2016a; Guzmán-Valenzuela \& Barnett, 2013).

Scene 7. At the beginning of our stay at the corridor, we enter the room of a professor in order to ask whether or not there are certain upcoming activities we can take part in. The professor turns to his computer screen and opens his calendar. After having made some arrangements for this week, we arrive at the next week. 'Next week I have nothing for you, though', the professor says. 'As you can see', he states whilst pointing at his screen, 'I have moved aside everything to above and below' [i.e. the next and the coming week - authors]. 'Next week is a writing week. I need to write a paper that is on my desk for way too long already'.

The prevalence of such remarks, which bear on the necessity of isolation, is paramount. For academics, it seems as if separation needs to be established in order to inaugurate a space and a time that is productive: productive 'work' - which mostly pertains to activities of writing - requires isolation and solitude, and hence a spatial and temporal separation from the corridor, one's colleagues and the visitors frequenting this space (Ylijoki \& Mäntylä, 2003).

In sum, even though the academics in this corridor are generally constantly busy and go from one activity to the next, all day long, there nevertheless equally is a tight clinging - a tight attachment - to isolated spaces and times, and hence to the effectuation of work that can hardly be performed when being in the corridor itself. These activities nearly always amount to writing. Notwithstanding that this isolation - this physical detachment in order to be able to attach oneself to activities of writing - is desired and actively sought, as stated, one equally is firmly attached to being in common spaces and times. It is precisely this constant academic oscillation between relating to solitude and common engagement that von Humboldt (1810) already pointed at more than two centuries ago: in order to be able to speak (which is always some sort of a public act), one needs isolation and solitude required for thinking and writing, and the other way around, that is, in order to be able to write, one first has to have something to write about (such as the arguments raised in a seminar, or one's experiences when one is out in the field).

\section{Mobilizing}

Scene 8. The lecture hall is crammed with students. After having introduced a particular scholar and having elaborated upon his general thoughts, the lecturer introduces some core elements of a text included in the 
course's reader. More particularly, she elucidates 'how to read this scholar'. During this argument, she relates back to other texts that the students already ought to read in view of previous lectures. 'And that comes back to some- thing we said before', the professor says. Or, 'Remember also that particular author. In the case of that author, we have seen ..., but for this author, ...'.

Scene 9. Today, a reporter is giving a guest lecture in view of the central theme of the course. On the front wall of the lecture hall, a slide show is again presenting a carousel of pictures. There is no text; just a concatenation of picture after picture after picture. The journalist's central claim is that there exists a huge gap between what mass media portray on the one hand, and what he calls 'mass reality' on the other hand. He justifies this claim by narrating about his own personal experiences in the field.

Scene 10. During a research methods workshop, the attending students are asked to form groups and discuss the methodology they (are going to) adopt in their own research project, based on a couple of texts they were asked to read beforehand. In one group, the discussion is very scattered and meanders from chatting about daily concerns to conceptual discussions about terms used in some of the texts (by leafing through the text, searching for connections, referring to other texts, etc.), and finally equally about how to write a thesis oneself. One student remarks that 'it amounts to playing with concepts and structures. It's all a game'. The other students giggle. When the lecturer joins the group, the discussion immediately is a lot more focused. The lecturer strews suggestions to each of the different students: 'That's great! I'll align you with a group of researchers who are exactly doing this'; 'You could use author Z'; 'Consider the spatial turn in the social sciences'; 'Some very good fiction has been written about this'; etc.

Which relations appear in these scenes, all situated in educational settings? To start with, the academic emerges here as a person who constantly and actively refers to other authors, texts, broader theoretical movements, fiction, etc. By referring, the academic draws her own argument into a broader realm of other arguments, thereby making her own individual argument weaker (i.e. no longer pertaining to her individual self) in order to make the claim as such stronger (i.e. undergirded by other views and arguments). In the context of scientific inquiry, Latour (1987) has coined this activity of referring as a 'mobilization of allies'. This mobilization appears to be not only characteristic for the conduct and reporting of (natural) science but also equally for academic education: students master this habit of referring very soon and conceive it as a 'game' of which they have discovered some hidden rules; academics play this 'game' both in their lectures and readers; etc. This constant referring makes the academic come into being as someone who has something to say, that is, as somebody original: not only is she someone who is always able to frame, contextualize, relate, etc.; it is precisely because she constantly refers to others and the work these other people are doing that she can make clear that she equally has something original to state herself. This differs from the (figure of the) journalist, for instance: the journalist reports of his own experiences, based on his own research in the field. This is where the journalist obtains his legitimacy from: from having been a witness of something at the moment of its occurrence. For academic practice, however, this is not enough: settings need to be related to theories and literature - sometimes translated into one general term or concept, but especially in educational settings equally often provided as a whole (i.e. in the form of a text).

In this sense, what academics equally aspire to is a thoughtful and fecund mobilization of texts, concepts, and their proper development and use (only the concept or reference that is just right will do) in order to have something originally to contribute oneself. This equally applies to students, who are urged to relate to textual matters exactly likewise: to refer where necessary, to adopt the right concepts, to make the proper links between different theories and approaches, and so on. In other words: to be as specific as possible about what one refers to, in order to be able to say something of oneself. In doing so, textual matters, concepts and precision in using the right and proper texts and concepts, but equally the act of 
referring, constitute 'obligatory passage points' in the establishment of academic practice (Callon, 1986): it is something one has to attach oneself to in order to be able to speak for oneself, viz. as an original self. This implies an obligatory commitment with these texts and concepts: they need to be read and studied before one can say anything (of worth) at all. Overall, this fourth group of relations points to an attachment to such commitment: by and through invoking very precise concepts and texts that are apt to the situation at hand, the argument one is presenting is not only potentially original but is also equally rendered more distant (i.e. more factual, more scientific). As we argue in the next section, this distance is one of the central features of what academics aspire to in their daily activities, and is characteristic of these four groups of relations as a whole.

\section{On the mode of existence of academic practice}

It is crucial to note that these portrayed relations and the interplay that is a result of these relational attachments, have been presented here separately for the purposes of this analysis, but that these are not so easily discernible from each other in practice and often overlap (for instance, the presence of seminal texts could equally be analyzed in terms of their contributing to establishing a discipline). In that sense, it is the inter- twined combination of these attachments that constitutes the generic passage point in order to get something 'academically' done.

But what is contained in these four attachments? What is characteristic of these groups of attachments as a whole, that is, when conceived together, how can these four groups of relations be characterized? Is there anything typical to discern that might show to what academics aspire to relate precisely? What are characteristics of an academic way of being? It could be stated that what these four sorts of attachment have in common is a directedness at distancing in action, to converse Latour's claim that science is characterized by action at a distance. With this expression, Latour (1987) argues that the scientific mode of existence operates in such a way that it creates centers that are able to act at many other, distant, points. Think of an observatory in which a scientist is able to see the sun and the stars by means of projections generated by a telescope and rendered on a screen, for instance. The astronomer does not need to travel to the sun or the stars in order to make legitimate claims about these celestial bodies because the telescope enables to see them here, in this observatory in the first instance, and to perform further operations in order for the telescope to look more precise in the safe confines of this computer-equipped room in the second instance. To act (to gaze in space, to make notes, to collect facts as researcher) upon something (an object such as the sun) at a distance (in an observatory, and not in a space ship) is according to Latour one of the prime features by means of which science can be characterized. Is such action at a distance what qualifies the academic practices we have aimed to characterize here? Only to some extent: although distance as such indeed constitutes a focal component of an academic way of being (e.g. by projecting carousels of distant visualizations or by isolating oneself from the corridor in order to think and write), it is not so much directed at the intention (or purpose) to act upon these distant actors. Rather, it could be stated that a prime characteristic of the academic mode of existence is situated in a continuous striving for, and aspiring to, distancing - or to phrase this otherwise, as a way of relating that is common to these four forms of attachments. Distancing constitutes an activity (hence: in action) on behalf of the academic, and this in two different respects. First, distancing points to the act of drawing various specific elements together, of actively mobilizing what is not present and thereby making it present. Second, distancing as an act that aims to slow things down and that seeks to suspend the daily course of activities.

First, then, distancing in the sense of making present what is not there. This is one of the prime features of the academic mode, be it in lectures, meetings, seminars or other activities we observed: the distant is 
constantly made present. By creating common spaces and times in one's own research center and by mobilizing, authorizing and purifying various features of the outside world, that is, by drawing various distant elements together in a setting, this setting does not so much transform in a center that acts at a distance as it transforms into a hub that draws (links, refers to, etc.) various particularities and singularities together. The accumulation of the particular (stories, anecdotes, pictures, movies, etc.) and the singular (a book, a person) make, for instance, that academic practice comes into being as a practice that has the potential to establish both generality and universality. As such, for academic practice the significance of distancing is not so much chiefly to be able to - potentially - return to the places in the field one is visualizing or making arguments about, but rather to accumulate the particular and the singular in such a way that the particular and the singular start to operate as a grid of conceptualized processes and evolutions that can and need to be put over other particularities and singularities. This at once enables and requires the exploration and localization of other cases: by means of such grids, exploring and localizing the distant is at once facilitated and becomes a priority. The mobilization of specificities, which is effectuated by displaying, narrating about, connecting and referring to the distant in action, constitutes a prime driver in furthering one's discipline. What circulates in this academic regime, then, are not so much exclusively 'objective' facts but rather a continuous flow of specificities that enables to make general claims and universalizing statements pertaining to the discipline one is in.

Second, the mode of existence of academic practice can equally be qualified as a mode that continuously seeks and aspires to distance oneself from the daily course of activities, that is, that continuously strives to slow things down. Even though academics are nowadays notoriously time-poor and involved in very diverse activities (teaching, supervision, research, publishing, administration, networking, ...), these four groups of attachments nevertheless point to the observation that academics continuously aspire to slow down the daily course of activities. Developing and using the proper words and concepts, for instance, takes a lot of time and does not come about naturally; blocking a whole week (as head of a research center) in order to write a paper slows down the daily course of activities in the research center itself; fine-tuning and adapting conceptual frameworks and methodologies to what is expected in the discipline slows down the research process; etc. Even though 'slowness' might be negatively associated with 'inertia', we advocate for a positive interpretation of the concept that precisely points to the academic aspiration of not going too fast, of hesitating, of thoughtful action and so on (see also Gosselain, 2011; Stengers, 2011): one needs to use and develop proper concepts in order to make sense of what one is talking about; one needs to withdraw oneself in order to be able to think; one needs to read many different texts in order to be able to take an original position; one needs to distance oneself from daily routines and actions in order to write; etc. Even in day-to-day meetings, one constantly hears questions and utterances that are slowing things down ('What do you mean with this term?'; 'Is this the proper way of conceptualizing the problem?'; 'How does this relate to the discipline...?'; ...). These are activities that need time and space, and that are in this very sense about distancing oneself from daily routines. There is a speculative hypothesis to make here that perhaps it is no coincidence that we were kindly asked to preferably not observe individual activities (primarily performed through the computer): perhaps the computer is the place (or the space) par excellence where this slowness is not always to be found, in the sense that this not only constitutes a hopping from one professional activity to the other (emailing, searching the internet, writing a paragraph, reading a note, ...) but also equally a hopping from one mode of existing to another (e.g. from an academic mode to a managerial or familial mode). This is not to say that the computer is a device that only accelerates: in isolated space and time, it might act as a device that is effectively able of slowing things down (Decuypere \& Simons, 2016a). 


\section{Concluding thoughts}

By giving an account of what academics in this corridor aspire to, and the specific sorts of relations that academics seek to establish, this article has tried to open the black box of daily academic practice. Of course, this article has presented a study of academic work as it is effectuated in Western (research) universities. In that sense, this study is situated within the research tradition studying these particular sorts of universities (largely situated in European, American and Australian contexts), but does not aim to make general claims with respect to 'the university' as such (and other parts of the world) (Barnett, 2011; Etzkowitz, Webster, Gebhardt, \& Terra, 2000; Fanghanel, 2012). To phrase it differently: the aim of this study was not to find the/an 'essence' of academic practice or some universal features that would be characteristic of all academics in every university. Rather than searching for essences, and more specifically in line with Latour's (2013) inquiry into modes of existence and Deleuze's (1994) conception of an untimely empiricism, the purpose of this article was to give an account of some typical academic features that emerge in day-to-day academic work, which might in their turn generate other accounts of the university as the ones we are currently familiar with (such as, for instance, the current focus on neoliberalism and its role in/impact on contemporary university governance). Approaching the university as in the making - that is, through daily academic practices - enabled us to come up with a different, untimely, account of the university and has hopefully shown the ways in which daily academic work, and its typical relations and aspirations, showcase resilience against external pressures toward the university. We end this article with two additional thoughts. First, the tendency to categorize academic practice into different roles or functions perhaps too readily assumes that such categories are the focal points of interest that require theoretical and/or empirical scrutiny and analysis. Classical conceptualizations of the academics' task into research, teaching and service, for instance, are perhaps not the most beneficial manner in order to come to grips with how academics and universities exist nowadays: focusing on differences between these activity domains potentially obfuscates what all of these activities have precisely in common, that is, the attachments through which academic practice comes into existence (cf. Boyer, 1990; Macfarlane, 2011). Second, even though the current condition of the university is often largely perceived pessimistically, we would like to draw this article to a close on a positive note. What this analysis has hopefully made clear, is that academic practice not only comprises specific and typical sorts of relations and aspirations but also equally that this way of existing is - at least in daily practice - by no means completely usurped by societal pressures that seek to impose neoliberal ways of thought and being onto contemporary universities. In that sense, this study has presented some elements of academic practice that are perhaps more and more marginalized, but that are nevertheless still present in contemporary academia. This equally opens up a space in which to think and wonder about these more ineffable parts of academic work, which make that universities are (still) unique institutions (and not corporations, for instance) (Wilkinson, 2010). Of course, we could have produced an account focusing on what is often designated as 'bureaucratization' or 'marketization'. However, if one puts such overarching and (proclaimed) determinative structuring evolutions between brackets in observing the specific types of activities that are being conducted in these two research centers, it is clearly apparent that the university is (still) constituting a mode on/of its own, instead of being singularly determined by such evolutions.

\section{Notes}

1. Of course, academics are only one group of people inhabiting contemporary universities (amongst students, management, secretaries, maintenance personnel, etc.). In that sense, this article delimits what happens at universities to what academics do in these universities. This is a reductive move, yet at the same time based on 
the argument that the specificity of the university is largely to be situated in work that academics perform on a daily basis (rather than that of secretaries or management, for instance) (Barnett, 2011).

2. In view of safeguarding the participants' anonymity, concrete anecdotes and/or stories are not provided as scenes in this article.

\section{Disclosure statement}

No potential conflict of interest was reported by the authors.

\section{Funding}

This work was supported by the Research Foundation Flanders 


\section{References}

AIME. (2013). An inquiry into modes of existence. Retrieved from http://www.modesofexistence. org/

Alvesson, M. (2003). Methodology for close-up studies - Struggling with closeness and closure. Higher Education, 46, 167-193. doi:10.1023/A:1024716513774 Barnett, R. (2011). Being a university. London: Routledge.

Bok, D. (2003). Universities in the marketplace: The commercialization of higher education. Princeton, NJ: Princeton University Press.

Bourdieu, P. (1988). Homo academicus. Stanford, CA: Stanford University Press.

Boyer, E. L. (1990). Scholarship reconsidered: Priorities of the professoriate. Lawrenceville, NJ: Princeton University Press.

Callon, M. (1986). Some elements of a sociology of translation. In J. Law (Ed.), Power, action and belief: A new sociology of knowledge (pp. 196-223). London: Routledge.

Collyer, F. M. (2015). Practices of conformity and resistance in the marketisation of the academy: Bourdieu, professionalism and academic capitalism. Critical Studies in Education, 56(3), 315-331.

doi: $10.1080 / 17508487.2014 .985690$

Dall'Alba, G. (2012). Re-imagining the university. Developing a capacity to care. In R. Barnett (Ed.), The future university (pp. 112-122). London: Routledge.

Decuypere, M., \& Simons, M. (2014). On the composition of academic work in digital times. European Educational Research Journal, 13(1), 89-106. doi:10.2304/eerj.2014.13.1.89

Decuypere, M., \& Simons, M. (2016a). What screens do. The role(s) of the screen in academic work. European Educational Research Journal, 16(1), 132-151. doi:10.1177/1474904115610335

Decuypere, M., \& Simons, M. (2016b). Relational thinking in education: Topology, sociomaterial studies, and figures. Pedagogy, Culture \& Society, 24(3), 371-386. doi: 10.1080/14681366.2016.1166150

Deleuze, G. (1994). Difference and repetition. (P. Patton, trans.). London: Athlone Press. Donoghue, F. (2008). The last professors. The corporate university and the fate of the humanities. Fordham, NY: Fordham University Press.

East, L., Stokes, R., \& Walker, M. (2014). Universities, the public good and professional education in the UK. Studies in Higher Education, 39, 1617-1633. doi:10.1080/ 03075079.2013.801421

Etzkowitz, H., Webster, A., Gebhardt, C., \& Terra, B. R. C. (2000). The future of the university and the university of the future: Evolution of ivory tower to entrepreneurial paradigm. Research Policy, 29, 313-330.

Fanghanel, J. (2012). Being an academic. Abingdon, UK: Routledge.

Feldman, M. S., \& Orlikowski, W. J. (2011). Theorizing practice and practicing theory. Organization Science, 22(5), 1240-1253. doi:10.1287/orsc.1100.0612

Fenwick, T., \& Edwards, R. (2010). Actor-network theory in education. London: Routledge.

Giroux, H. A. (2002). Neoliberalism, corporate culture, and the promise of higher education: The university as a democratic public sphere. Harvard Educational Review, 72(4), 425-464.

doi:10.17763/haer.72.4.0515nr62324n71p1

Gosselain, O. P. (2011). Slow science - La désexcellence. Uzance, 1, 128-140. 
Guzmán-Valenzuela, C. (2015). Unfolding the meaning of public(s) in universities: Toward the transformative university. Higher Education. doi:10.1007/s10734-015-9929-z

Guzmán-Valenzuela, C., \& Barnett, R. (2013). Marketing time: Evolving timescapes in academia. Studies in Higher Education, 38(8), 1120-1134. doi:10.1080/03075079.2013.833032

Hakala, J. (2009). The future of the academic calling? Junior researchers in the entrepreneurial university. Higher Education, 57(2), 173-190. doi:10.1007/s10734-008-9140-6

Hamon, H., \& Rotman, P. (1981). Les Intellocrates: expédition en Haute Intelligensia. Paris: Editions Ramsay.

Harpham, G. G. (2005). Beneath and beyond the” Crisis in the Humanities”. New Literary History, 36(1), 2136.

Harvey, D. (2005). A brief history of neoliberalism. Oxford: Oxford University Press.

Hillyard, S. (2010). Ethnography's capacity to contribute to the cumulation of theory: A case study of strong's work on Goffman. Journal of Contemporary Ethnography, 39(4), 421-440. doi:10.1177/0891241610366710

Hodgson, N. (2014). Materials that shape researchers. In P. Smeyers \& M. Depaepe (Eds.), Educational research: Material culture and its representation (pp. 87-96). Switzerland: Springer.

Kittler, F. (2004). Universities: Wet, hard, soft, and harder. Critical Inquiry, 31(1), 244-255.

doi:10.1086/427310

Knoblauch, H. (2005). Focused ethnography. Forum: Qualitative Social Research, 44, 3.

Landri, P. (2012). A return to practice: Practice-based studies of education. In P. Hager, A. Lee, \& A. Reich (Eds.), Practice, learning and change (pp. 85-100). Dordrecht: Springer.

Latour, B. (2005). Reassembling the Social. An introduction to actor network theory. Oxford: Oxford University Press.

Latour, B. (1987). Science in action. Boston, MA: Harvard University Press.

Latour, B. (1999). Factures/fractures. From the concept of network to the concept of attachment. RES, 36(Autumn), 20-31.

Latour, B. (2013). An inquiry into modes of existence. Cambridge, MA: Harvard University Press. Law, J. (2009). Actor network theory and material semiotics. In B. S. Turner (Ed.), The new Blackwell companion to social theory (pp. 141-158). Chichester, UK: Blackwell Publishing.

Lenartowicz, M. (2015). The nature of the university. Higher Education, 69, 947-961. doi:10.1007/s10734014-9815-0

Lynch, K. (2015). Control by numbers: New managerialism and ranking in higher education. Critical Studies in Education, 56(2), 190-207. doi:10.1080/17508487.2014.949811

Macfarlane, B. (2011). The morphing of academic practice: Unbundling and the rise of the para-academic. Higher Education Quarterly, 65(1), 59-73. doi:10.1111/hequ.2011.65.issue-1

Marginson, S. (2011). Higher education and public good. Higher Education Quarterly, 65, 411- 433. doi: $10.1111 /$ j.1468-2273.2011.00496.x

Marginson, S., \& Considine, M. (2000). The enterprise university: Power, governance and reinven- tion in Australia. Cambridge, MA: Cambridge University Press.

Mol, A. (2002). The body multiple. Durham, NC: Duke University Press. 
Murphy, E., \& Dingwall, R. (2007). Informed consent, anticipatory regulation and ethnographic practice. Social Science \& Medicine, 65(11), 2223-2234. doi:10.1016/j.socscimed.2007.08.008

Nóvoa, A. (2015). Looking for freedom in contemporary universities: What is educational research for? European Educational Research Journal, 14(1), 3-10. doi:10.1177/

1474904114563459

Nussbaum, M. C. (2010). Not for profit: Why democracy needs the humanities. Princeton, NJ: Princeton University Press.

Olssen, M., \& Peters, M. A. (2005). Neoliberalism, higher education and the knowledge economy: From the free market to knowledge capitalism. Journal of Education Policy, 20(3), 313-345.

doi:10.1080/02680930500108718

Ong, A. (2007). Neoliberalism as a mobile technology. Transactions of the Institute of British Geographers, 32(1), 3-8. doi:10.1111/j.1475-5661.2007.00234.x

Petersen, E. B. (2009). Resistance and enrolment in the enterprise university: An ethno-drama in three acts, with appended reading. Journal of Education Policy, 24(4), 409-422. doi:10.1080/ 02680930802669953

Pink, S., \& Morgan, J. (2013). Short-term ethnography: Intense routes to knowing. Symbolic Interaction, 36(3), 351-361. doi:10.1002/symb.2013.36.issue-3

Readings, B. (1996). The university in ruins. Camhridge, MA: Harvard University Press.

Rose, N. (1999). Powers of freedom. Reframing political thought. New York: Cambridge University Press.

Shore, C. (2010). Beyond the multiversity: Neoliberalism and the rise of the schizophrenic university. Social Anthropology, 18(1), 15-29. doi:10.1111/(ISSN)1469-8676

Simons, M., \& Masschelein, J. (2009). The Public and its university: Beyond Learning for Civic Employability? European Educational Research Journal, 8, 204-217. doi:10.2304/ eerj.2009.8.2.204

Slaughter, S., \& Rhoades, G. (2004). Academic capitalism and the new economy. Baltimore, MD: John Hopkins University Press.

Stengers, I. (2011, December 13). “Another science is possible!” A plea for slow science. Inaugural lecture Chair Willy Callewaert. Brussels: VUB.

Torres, C. A. (2011). Public universities and the neoliberal common sense: Seven iconoclastic theses. International Studies in Sociology of Education, 21(3), 177-197. doi:10.1080/ 09620214.2011.616340

Vander Kloet, M., \& Aspenlieder, E. (2013). Educational development for responsible graduate students in the neoliberal university. Critical Studies in Education, 54(3), 286-298. doi:10.1080/17508487.2013.826706

Venturini, T. (2010). Diving in magma: How to explore controversies with actor-network theory. Public Understanding of Science, 19(3), 258-273. doi:10.1177/0963662509102694

von Humboldt, W. (1810). On the internal and external organization of the higher scientific institutions in Berlin. http://germanhistorydocs.ghi-dc.org/pdf/eng/16_ScienceandEducation_

Doc.4_ENGLISHxxxTRANS.pdf

Wilkinson, J. (2010). Is it all a 'game'? Analysing academic leadership through a Bourdieuian practice lense. Critical Studies in Education, 51(1), 41-54. doi:10.1080/17508480903450216 Ylijoki, O. (2014). University under structural reform: A micro-level perspective. Minerva, 52(1), 55-75. doi:10.1007/s11024-014-9246-1

Ylijoki, O., \& Mäntylä, H. (2003). Conflicting time perspectives in academic work. Time \& Society, 12(1), 5578. doi:10.1177/0961463X03012001364 